\title{
Retrospective Analysis of Development of Special Economical Zones in the Russian Federation
}

Terenteva Elena Anatolevna

Educational non-profit organization "Institute of world economics \& finance", Astrakhan, Russian Federation

Email: eterenteva@imef.ru

\section{Vasilenkova Nadezhda Vladislavovna}

Astrakhan State Technical University, Astrakhan, Russian Federation

\section{Doi:10.5901/mjss.2015.v6n3s3p319}

\section{Abstract}

Advance of special economical zones is an integrated economical instrument of regional development. The primary goal of economical zones creation is solution of region questions in strategic, territorial, social, economical, scientific and technological aspects. To resolve the main governmental and regional tasks in countries with developed and developing economy special territories that get special tax and economical privileges and special legal status for attraction of national and foreign investors are created. Thus, the special economical zones promote development of priority branches of national economy, small- and mid-sized enterprises, fruitful interaction between business entities and government. In the paper stages of development and effectiveness of applying special economical zones on the example of economy of the Russian Federation are considered, features of zones' functioning peculiar to definite historical period of national economy development. The main goal of research performed by authors is the analysis of the features of special economical zones' functioning at the modern stage of national economy development. There are also an overview of special economical zones functioning today on the territory of Russia and the results of their application. The present work is the attempt of authors to expose multidimensional nature of "special economical zones" category. The key reasons for low-effective activity of separate economical zones on the territory of Russian Federation.

Keywords: special economical zones, exclusive zones, economical relations, investment attraction, branches of industry, partnerships, regional development.

\section{Introduction}

Special economical zones can be considered one of the main components of economical relations in modern national economy. In mega-economical connections economical zones are recognized as a mean for acceleration of growth due to intensification and extension of trade turnover, activization of investment activity, performance of integration processes.

One of the examples of effective application of SEZ (special economical zones) is the experience of China (JungDong Park, 1997), which demonstrate the highest rates of economical growth among the rest of countries and territory regime of which for one third consists of special economical zones.

Study of national experience of special economical zones' application witnesses existing a number of reasons, in consequence of which SEZ had been developing and operating in such ineffective and in some cases were unprofitable.

Besides, there were problems of organization and legal character that had not been promoting application of economical zones and economical growth of economy, which is possible under condition of reasonable use of exclusive feature of considered zones. That is why research and resolving tasks linked to effective formation and functioning of SEZ is one of general fields of concern in business of the Russian Federation.

However, despite existing researches of special economical zones development, the necessity of analysis of stages of zones functioning in historical retrospective, which can form effective mechanism of their creation and activity under recent crisis conditions in national economy. Such a classification of SEZ by the spheres of activity and suggested privileges and tax indulgences presented in the paper provide clear vision of zones' activity, their effectiveness and the necessity of creation and prospects of application. 


\section{Literature Review}

Analysis of foreign practice shows the effective functioning of special zones promotes not only rapid development of country's economy, but also provides help in reaching leading positions in national economy (Deborah Bräutigam and Tang Xiaoyang, 2011; Lotta Moberg, 2015; Palit Amitendu, 2008).

In addition, special zones upon modern conditions have global character and cover the whole mega-economical system, including prosperous and subsidized economical entities, with help of which quite intense integration of entire regions into the system of mega-economical relations that largely promotes development of separate regions' economy (Blinnikov E.B. \& Leonidova A.I., 2010).

At the same time formation of special economical zone means that national economy that does not want to open its internal market for foreign capital or ubiquitously use special investment climate resorts to partial, local openness in the form of exclusive zone. In recent decade in the world's economy intense competition between countries in the area of tax and other privileges presented for attraction of capital from other countries has spread. A wave of tax privileges of various kind fixed by national legislations has got the name of "tax revolution". In this process special economical zones play rather significant role (Krasnoslutskaya N.T., 2007) and become real method for attraction of external investments, including foreign capital (Mikhaylushkin P.V. \& Barannikov A.A., 2013).

The relevance of special economical zones' research was proven in works of many researchers. The zones are considered an instrument of innovative development of economy that allows resolving tasks for support of innovative process and development of high-tech branches (Korolev Y.A., 2010; Mironov E.I., 2010; Orlov A.K., 2012; Shvetsova K.A., 2012).

We should also note the special contribution to studying categorial structure of special zones in works of Russian scientists, who considered different aspects of SEZ functioning. Among them there are: Andreev V.O., Anischyuk Y.P., Asaul A.N., Voinov N.A., Danko T.P., Druzik Y.S., Kostromicheva E.V., Ostrovsky V.M., Potanin V.F., Rodionov A.P., Savin V.A., Semenov G.N., Smirnov A.M., etc.

\section{Methodology and Methods}

The conducted study presented in the present paper is based on approaches and concepts of foreign and national scientists that had been reflected in scientific works aimed at studying questions of reasonable formation and effective functioning of area with special economical regime, improvement of regulatory system and economical mechanism of SEZ.

In the process of studying we applied general scientific methodology with use of systematic approach to set tasks, institutional approach to consideration of "special economical zones" category, general scientific methods of systematic and functional, historical and logical, comparative analysis, and also economical and mathematical methods for information processing. The empiric base of conducted study is the official governmental statistical data and the information presented by bodies performing administration and functioning of SEZ in the Russian Federation, etc.

In the lay-outs of some scientists it is generally accepted to subdivide the stages of economical zones in national economy into three time intervals (Orlov A.K. and Buadze E.R., 2012) that are characterized with independent endogenic logic of development and have definite similarities and exclusives.

The first time interval is characterized with formation and stating task about necessity of creation of economical zones and dated 80-90s years of XX century. The peculiarity of the period was that in Soviet Union the possibility for foreign investments had emerged. This promoted attraction of new sources for financing of national economy. The decision about creation of economical zones was to great degree affected by positive experience of China that was taken as basis during formation of first zones. For the purpose of increase of effectiveness of special economical zones activity in the USSR the definite conditions were provided. These conditions are characterized with:

a) location in specific limited area;

b) the most investment-attractive climate for foreign persons.

The main purpose of launched project was application of foreign experience and methods for functioning of business with its subsequent use out of economical zones.

The present zones should have been a springboard used by the Soviet Union in its transition from commandadministrative to market economy.

The project was formally confirmed by the Decree of the CPSU Central Committee and Ministry of the USSR of December 2, 1988 \#1405, which provided formation of such special economical zones (SEZ) as "Vyborg" (the Leningrad region) and "Nakhodka" (Primorski Krai). These very subjects had become first experimental areas. Later the rest regions 
of former plan system had also prepared projects on formation of economical zones. In fact, the zones become an economical entity that requires constant governmental financing, the fact of which was used by the republics of the Soviet Union and regions for getting autonomy and acquisition of economical independence. There were many suggestions about creation of economical zones in new regions, what could tangibly affect the stability of country's budget.

The end of XX century in national economy was characterized with regulatory confirmation of economical zones in different regions: SEZ "Eva" (Jewish autonomous region); SEZ "Altai"; Leningrad zone of free enterprise; SEZ "Kuzbas" (Kemerovo region); SEZ "Sadko" (Novgorod region); Free economical zone in Kaliningrad and Chita regions; SEZ "Sakhalin", SEZ "Yantar" (Kaliningrad); SEZ "Technopolis Zelenograd"; ecological and economical zone of "Gorni Altai".

It is necessary to note that under conditions of legally fixed standards for existence of economical zones its basic principles of activity had been remaining transparent and inexplicit as before. The first step towards settlement of problems was adoption of the Law "Of foreign investments in RSFSR" in 1991 that had defined main goals of creation of economical zones as: 1) influx of capital of foreign investors; 2) practical application of new technologies; 3) training and employment assistance of highly-skilled managers in national economy.

The political instability evinced in Russia in 90s years of XX century had significantly reduced investment interest in national economy. Under such circumstances the further investment of SEZ becomes non-prospective, and regions could not independently support functioning of zones in difficult economical situation.

Due to unfavourable situation the decision of liquidation of zones taken almost one third of national economy. The period was also linked to reduction of territory occupied by zones, decrease of privileges' volume, etc.

Now, instead of giant in territorial scale zones there were small, territory-limited micro-zones required for no special infrastructure (by the Order of President of Russia of December 10, 1992, "Sheremetievo" free trade zone was created; by the Order of June 3, 1993 SEZ "Sherrizon" ("Sheremetievo-2") was established; by the Order of President of the Russian Federation of February 25, 1993 and the decree of government of June 19, 1994 - "Ingushetiya" free economical zone was created).

An evident significant disadvantage preventing form effective functioning of economical zones is the predominance of quantitative methods over qualitative ones and the lack of attention to the specificity of national economy.

The initial stage of SEZ formation can be characterized with ambiguity of adopted target goals and inaccuracy of tasks for economical zones, predominance of quantitative methods in zones' development; non-earmarked funding, uncontrolled distribution of privileges and formation of opportunities for economical independence of regions by the means of zones' formation.

The next stage of economical zones' formation covers the period from 1995 to 2005. Within the period two fundamental regulatory acts were adopted: the Federal law of 05.31.1999 \#104-FL "Of special economical zone in Magadan region" and the Federal law of 01.22.1996 \#13-FL "Of special economical zone in Kaliningrad region".

In fact, the results of adoption of regulatory acts in 90 s had taken place only in 2000s. Due to special geopolitical significance, territorial detachment of regions of entire national economy, the economical zones are being united with the only goal - to develop regional economy, not only interested foreign investors. Besides, another one innovation was the establishment of terms of special economical zones' functioning: on December 31, 2014 the zone in Magadan region was stopped, on April 1, 2006 - the zone in Kaliningrad region ceased to function.

In the period of economical zones' activity there were positive trends in national and regional economy, particularly, the increase of gross regional product, reduction of unemployment level.

We should specify that at the present stage there was rethinking of goals, tasks and functions of special economical zones - instead of being an instrument granting access to national economy for foreign investors, they had turned into a driver of regions' economical development. Specialists had not agreed in assessment of SEZ activity effectiveness, however, it should be noted that the application of economical zones had become a powerful impact for territorial development of national economy. The development of zones possesses targeting to internal market, orientation at their adaptation to new economical conditions.

The third stage of economical zones' functioning starts from 2005 with formation of legislation for special zones. At the stage different aspect of economical zones' activity were developed, thus, the Federal law of 07.22.2005 \#116-FL "Of special economical zones in the Russian Federation', basic regulatory concepts and ZES functioning principles were adopted. Based on the present federal law there was a number of Government's decrees concerning creation of economical zones in different regions. Later the system of assessment of economical zones was developed: firstly, by the means of "Formation of favourable investment environment" subprogram of "Economical development and innovative economy" national program of the Russian Federation that was approved by the Decree of Government of the Russian Federation of December 21, 2013 \#2492-p; secondly, by Rules for assessment of SEZ functioning effectiveness that were approved by the Decree of the Russian Federation of June 10, 2013 \#491. 
However the economical assessments of SEZ functioning effectiveness are imperfect and that is why it is being reasonably to perform analysis of effectiveness of administrative company of the present zone when making assessment.

Besides, there was selection of applications when modeling economical zones, The decree of Government of the Russian Federation of 04.26.2012 \#398 "Of approving criteria for creation of special economical zone" had formalized the basics for selection of applications for zones' creation.

For the purpose of increase of effectiveness of economical zones Government issued the Federal law of July 23, 2013 \#231-FL "Of introducing changes to articles 4 and 10 of Federal law "Of special economical zones in the Russian Federation" that had implied making processing of raw materials, except for hydrocarbon, the authorized type of activity in special economical zones.

An innovatory was the decision of Government of the Russian Federation of 2013 - the Decree of 06.21 .13 \#524 providing governmental support for administrative companies and residents of tourist and recreational zones that were combined to cluster by the decision of the Government.

Special economical zones are the part of economical national space, which is being under effect of special privileged system of impetuses that do not cover other parts of macro-economy. As a rule, a special economical zone is being to this or that degree a detached geographical territory.

When analyzing zones of different types in scientific publications and reports of international organization there is a concept of "free economical zones" (Babaev K.S., 2014; Berezenkov V.V. et al.; 2010, Korobova O.V., 2010). However the present concept reflects the essence of the phenomenon to quite a minor degree.

Thus, the economical levers and rules applied in many of the, as well as special administrative rules do not release residents from definite legal and economical regime, but just facilitate it, grant privileges that promote business. In fact, the government only reduces the scales of its intermediation in economical processes.

For some countries the "special zones" are being exclusive in terms of extraterritoriality, standards of living of workers of a zone, concentration of production potential, etc. For such zones there is a more appropriate term of "special economical zones".

The creation of SEZ and their functioning goals are based on the level of organizing countries' social and economical development, and also on the strategy of national economy development. In this connection the goals and reasons for zones' creation can be various. For example, in the USA, France, Great Britain economical zones are created for the purpose of activation of international economical relations, realization of tasks of regional policy aimed at support of small- and mid-sized business in the areas with depressed economy, counterbalance of differences between regions. For the purpose of realization of above-numbered goals business-entities in the areas of economical zones' functioning had got more freedom of choice than business-entities of other areas. The programs possessed no special orientation at attraction of foreign capital (Rybakov S.A., 2006).

For similar purposes special economical zones had appeared in the countries with developing economy. However, we should note that in such countries the emphasis is put on attraction of foreign investments, highly skilled staff, its retraining and also the modernization of industry as a whole.

Except for named purposes the creation of SEZ has a number of main tasks: firstly, promotion of industrial export and getting funds; secondly, increase of employment level thirdly, turning of zones into testing grounds for proving new administration methods and growth of national economy.

Founders of SEZ consider them the possibility of realization of national economy principles, its openness. The active application of special zones is geared to development of economical relations, foreign economic bonds, international partners, etc.

In practice there are such forms that should reflect the entire diversity of system of economical relations and have positive impact on effectiveness of SEZ functioning, as Institute of public and private partnership (Vasilenkova, 2014).

In the framework of zones the national economy possesses significant degree of openness to macro-economical system, while special regimes (customary, administrative, tax, etc.) are being favourable for exogenic and endogenic investments.

The special status was granted to economical zones by the Government of the Russian Federation, where innovative development is considered a powerful driver for economical growth and in the forecasts of which there are mechanisms for scientific product formation, its commercialization, that are planned to be realized, on the one hand, by means of investment in definite activity, subsidizing of interest rates, etc., and on the other hand - by means of creation of such infrastructure objects in regions as: technology parks, business-incubators, territorial innovative clusters. The Minister of economical development Ulyukaev A.V. urges to support innovative direction of economy development by means of special economical zones' application. From the point of view of an impact on medium-term economical growth this is being quite an efficient mechanism (Ulyukaev A.V., 2014). 
At the expense of federal budget funds in the economical zones there are special conditions for implementation of new technologies and improvement of principles and methods of quality-management system, in particular, the entire complex of infrastructure objects for scientific activity, research and development, and also for informational provision of all the entities of business.

One of the useful advantages of SEZ is their location. The expedient location is, for example, the intersections of major transportation routes, near to river and sea ports, airports that promote strengthening of interrelations with megaeconomical market.

Creation of special economical zones and their designation derive from the goals of their formation. Thus, for development of external trading relations there are zones of free trade; for improvement of production by means of attraction of national and foreign capitals industrial zones are created; for promotion of high-tech enterprises there are technological innovative zones; while for development of the sphere of services there are so called service zones.

The presented types of ZES have simplified functions, but within the zones there is a regime that provides application of advantages of several types of zones. Among such complex zone in different national economies we can figure out zones of free business, special economical zones, special regime territories (Smorodinskaya N., Kapustin A., 1994). Quite often the differences between such complex SEZ appear only in definition of the term used in various countries and in respect of specific purposes of their creation, while the instrumentation of zones' functioning remains alike.

SEZ can be classified by performing functions, the degree of integration to economy, the systems of granted privileges and the nature of economical freedom: zone of free custom territory, zone of free trade, export industrial zone, zone of mutual business, free "open" zones, technological zone, service zone, complex zone (Sidorenko V.V. \& Agasarov D.Y., 2006).

In national economy there are zones of four types: technical innovative, industrial, tourist-recreational and port special economical zones.

Industrial zone - a part of national system, inside of which production of specific industrial goods is set; investors in the present case get different privileges (Krasnoslutskaya N.T., 2007).

Technical innovative zone is the territory out of national space, inside of which there are scientific and research, design organizations. The examples of Technical innovative zone:

- the territory, on which there is tourist and recreational activity - creation, reconstruction, development of infrastructure objects, improving and rendering services in the sphere of tourism.

By the degree of economy integration:

1) National economy integrated zones;

2) Enclave (isolated) zones.

By systems of privileges:

1) Tax: the "tax holidays" - partial or full release of investors from paying taxes for property, etc. (in accordance with the law about SEZ that had come into effect on January 1, 2006, the residents of industrial zones are released from paying land, property and transport taxes, the income tax is reduced $4 \%$ (to 20\%), the lowering of tax rate from $26 \%$ to $14 \%$ is provided);

2) Tax (import) - partial or full release from import fees for semi-manufactured products, raw materials, etc. being imported for use within zone;

3) Tax (export) - partial or full release from export fees for the production made in zone;

4) Financial - investment subsidies, national privileged, reduced rates for payment of public facilities and lease of production premises;

5) Administrative - the simpler procedure of enterprises' registration, simpler procedure for entry/exit of foreign citizens, unrestricted exportation abroad of obtained income by foreign citizens (Rybakov S.A., 2006).

Entrepreneurship in special economical zone is promoted by way of application of even one of four groups of privileges, their combination depends on the type of economical zone:

- foreign trade privileges provide special custom-tariff regime (for example, cancellation or reduction of exportimport privileges) and simplify the order of performance of foreign trade transactions; foreign trade privileges is the feature of free trading zones, however they are applied in industrial and production and technical innovative zones. Among such complex zones in various countries one can distinguish zones of free business, special economical zone, special regime territories (Smorodinskaya N., Kapustin A., 1994). Often the difference between such complex SEZ can be found only in terms used by different countries and for specific purposes of their creation, while the instrumentation of zones' functioning remains alike. 
Table 1. Privileges in special economical zones

\begin{tabular}{|c|c|c|c|}
\hline No. & Privilege name & General provisions & Application \\
\hline 1. & $\begin{array}{l}\text { Foreign trade } \\
\text { privileges }\end{array}$ & $\begin{array}{l}\text { Imply introduction of special custom-tariff regime and simplify the order of } \\
\text { performance of foreign trade transactions. The foreign goods imported to the } \\
\text { territory of special economical zones are allocated and used without } \\
\text { payment of custom fees, taxes, and also without application of measures of } \\
\text { non-tariff regulation. The goods of Customs Union fall under custom } \\
\text { procedure of free custom zone without payment of export custom fee and } \\
\text { also without application of bans and limitations. }\end{array}$ & $\begin{array}{l}\text { The distinguishing feature } \\
\text { of free trade zones, } \\
\text { however they can be used } \\
\text { in industrial and technical } \\
\text { innovative zones. }\end{array}$ \\
\hline 2. & Fiscal privileges & $\begin{array}{l}\text { For residents of all the types of zones the reduced tax rate for income that is } \\
\text { subject to crediting to budgets of constituents of the Russian Federation is } \\
\text { set. Residents are released from payment of tax for property for the period of } \\
5-10 \text { years depending on the zone from the moment of property registration } \\
\text { in case of performance of the following conditions: the property was created } \\
\text { or purchased for purpose of carrying-out of activity within zone; the property } \\
\text { is in fact used on the territory of zone. Preferences on transport tax are set } \\
\text { by constituents of the Russian Federation, on the territory of which special } \\
\text { economical zones are created. For investors the privilege on transport tax is } \\
\text { granted at the moment of transportation vehicle registration. At federal level } \\
\text { investors are released from payment of land tax for } 5 \text {-10 year depending on } \\
\text { zone from the moment of emergence of property right to land parcel located } \\
\text { on its territory. }\end{array}$ & $\begin{array}{l}\text { Cover all the types of } \\
\text { special economical zones, } \\
\text { except for trade. }\end{array}$ \\
\hline 3. & Financial privileges & $\begin{array}{l}\text { Provide subsidies of different types in the form of low costs for public } \\
\text { facilities, rent for use of land parcels and industrial premises, and also due to } \\
\text { budget funds and preferential national loans. }\end{array}$ & $\begin{array}{l}\text { Most often used in } \\
\text { technical innovative zones }\end{array}$ \\
\hline 4. & $\begin{array}{l}\text { Administrational } \\
\text { privileges }\end{array}$ & $\begin{array}{l}\text { Include simplified procedure for enterprises' registration and entry/exit } \\
\text { regime for foreign citizens, as well as rendering various services. }\end{array}$ & $\begin{array}{l}\text { Used in all the types of } \\
\text { SEZ. }\end{array}$ \\
\hline
\end{tabular}

In addition, the business-entities that function in SEZ apply advantages provided by different governmental levels, and also the administration of SEZ itself. Such advantages include: a) political guarantees for stability of management conditions in economical zone for definite period of time; b) presentation of initial investment capital for modernization of infrastructure; c) provision of economical zones' organizations with highly skilled staff; d) assistance in resolving different types of conflicts in the framework of economical zone, when government undertakes conflict's settlement.

Number and typology of privileges in types' diversity of special economical zones directly depends on the readiness of government to perform assistance when attracting investments to regional economy. For the purpose of effective functioning of SEZ it is reasonably to consider them main instrument for solution of many tasks of national economy.

The economical zonation in national economy had begun in 80s years of XX century. The feature of special economical zones' formation is characterized with matching borders of the economical zones to the borders of national republics situated on large territories, excluding targeting of their creation.

However it was scientifically proven that the effectiveness of functioning of innovative system of technical innovative zones is formed as a part of national economy.

The technical innovative activity should be understood as creation and realization of scientific and technical production and its industrial application, including all the stages of production process, and also rendering services on implementation and maintenance of such products and systems. The technical innovative zones are the kind of special zones, the distinguishing feature of which is the concentration of research, project, scientific and production companies on small territory, as a rule, on basis of universities or by way of restructuring of industrial zones (Granbergh A.G., 2000). The technical innovative zones include: science cities, scientific and industrial parks. Granbergh A.G. refers free economical zones and zones of free business, including off-shore zones, to special zones. Thus, technical innovative zones are the kind of special economical zones.

Scientists of the Institute of regional economy problems consider free scientific innovative zones territorial complexes for science, education and highly developed production integration (Litovka O.P., Mezhevich N.M., 2002).

Another one distinguishing feature of technical innovative zones is the amalgamation of production and technical and scientific activities concentrated around major scientific center. The global goal of such zones' formation is the mobilization of probable labour and material resources for acceleration of implementation of new technologies into 
industry, provision with working places, diversification of regional economy and micro-economical system on the basis of activation of investment activity.

Depending on what aspect is being predominant in the structure of economical zone, there are three types of them:

The first type is the innovative center, the economical structure that occupies small territory and being most effective for small and young company.

The second type is the scientific park located on large territory with knowledge-intensive organizations of different sizes and level of development that provides conditions for production activity on the basis of scientific and technical layouts and local research center (university).

The third type is the research park that is represented as a structure, in the framework of which there is development of scientific and technical innovations to the stage of technical prototype. In research parks scientific and research, experimental and developmental institutions and industrial companies.

Analysis of world's experience of application allows making conclusion about perspective of technical innovative zones. The represented zones had been preferential form of export and production zones' development.

In general we should note significant success of special economical zones' functioning on the territory of the Russian Federation. Thus, private investments in special economical zones in the country (99,5 bln. roubles) in 2013 had exceeded the expenses of government for infrastructure (90 bln. roubles). The surplus of investment capital only for 2013 made $44 \%$ or $30,2 \mathrm{bln}$. roubles (for previous seven years $60 \mathrm{bln}$. roubles was invested by residents). This was declared by the head of Department of special economical zones, projects for regions' development and mono-cities of the Ministry of Economical Development Andrey Sokolov when summing up the results of activity of special economical zones in 2013.

Seven new enterprises was built and implemented into operation in 2013. Among the enterprises there are: SARIA Bio-Industries, "Biokad", MOJE Keramik-Implantate, ARKRAY, LANXESS, "Rakurs-Engineering", Bekaert. Construction of eight big plants and scientific and production complexes, among which there are such enterprises as $3 \mathrm{M}, \mathrm{GM}, \mathrm{AAR}$, Armstrong, FordSollers (engine plant), had started.

In 2013 tax payments to budgets of all the levels made 10,9 bln. roubles - that is 3,1 , bln. roubles more than in 2012. The volume of production made in special economical zone had increased $88 \%$ - from 56,8 bln. roubles to 107 bln. roubles. In such situation the earnings of residents had increased up to $50 \mathrm{bln}$. roubles (in $2012-29,7 \mathrm{bln}$. roubles). In 2013 there was 40\% increase of number of working places created in special economical zones - up to 10934.

In total in ZES 26 industrial enterprises and scientific and production centers were built.

Speaking about prospects, the head of Department of special economical zones, projects for development of regions and mono-cities of the Ministry of Economical Development Andrey Sokolov noted that this year the project of SEZ can be added with about 40 new residents. Every fifth company is foreign one (Austria, Germany, Italy, USA, Belgium, Turky, France, Japan).

Thereby, a number of companies, which by now finish formation of business-plans, will undoubtedly submission application, while a number of companies are being "treated" by as, as far as work with them, particularly, with major companies, is rather complicated and long-term process that in some cases takes years (Popova M.V.; Rubtsov N.M., 2014).

The biggest interest of investors is traditionally caused by production industrial zones.

In particular, 14 companies with announced investments of $16683 \mathrm{bln}$. roubles prepare to become resident of industrial zones. The volume of forecasted investments in innovative zones makes almost 6 bln. roubles, and here we speak about 21 companies. 13 more companies with announced investments of $16683 \mathrm{bln}$. roubles plan to enter tourist zones. It is also planed to attract two companies with forecasted volume of investments of $4421 \mathrm{mln}$. roubles to port zones.

In fact, the residents have invested every fourth declared rouble - 99,5 bln. roubles (23\% of total volume of declared investments, in 2012 the indicator was 18\%, in 2011 - 10\%) to the projects on the territories of SEZ.

In 2013 the administrative company "ZES" JSC had attracted 80 new residents with total volume of declared investments of 59,5 bln. roubles. Among theme there are global players: Abb (Switzerland-Sweden), GKN plc (UK), PPG Industries Inc. (USA). Thus, the number of resident of special economical zones had reached 370 companies from 28 countries from all over the world, including Russia. The total volume of investments declared by residents of SEZ as on January 1, 2014 had made 430 bln. roubles.

However, the absence of clear and transparent position of the country restrains entry of other foreign investors to Russian SEZ. For example, the big interest of a number of companies is caused by the project for creation of special economical zone in Sovetskaya Gavan port approved by governmental commission. However constant delays in formal procedures on getting of the SEZ into operation gradually reduce the interest of foreign investors by raising their 
skepticism in respect of the very idea of Russian port zones.

\section{Results and Discussion}

As it was mentioned, the key task of SEZ creation in the Russian Federation is the granting of attractive conditions for foreign investors that is promoted by extension of privileges regime, tax preferences, etc. on the presented territory.

The matter is that attraction of foreign investments in national special economical zones is restrained by a number of objective factors.

ROSIZO actively participate in attraction of foreign investors. The tasks of the agency are: a) participation in market researches; $b$ ) issuing of specialized materials; $c$ ) provision of wide range of economical zones' subjects with information; d) analysis of foreign experience of formation and functioning of special economical zones and its application in national practice; e) interaction with business-entities; f) direct communication with potential reviewers, etc.

However in general the efficiency of activity on attraction of foreign investors to national economy through economical zone remains low. Such a situation is related to the fact that national special economical zones offer smaller tax fees, than foreign countries, and that is why they are being less attractive for capital investment.

In terms of world's standards Russian SEZ possess relatively low tax fees and remain not so attractive for foreign investors. In fact, government reduces only regional and local taxes, that is why it appears to be necessary to expand the privilege mechanisms due to federal part of taxes and fees.

The world's experience shows that the functioning of SEZ is affected by the following factors: a) political stability; b) investment guarantees; c) quality of infrastructure, d) qualification of working power; e) simplification of administrative structures. The world's practice provides two main variants of free economical zones' creation. Virtually, they can be called "above" and "below". The "above" variant implies that formation of zone is taken place by initiative of central (federal) authorities and in the framework of national program (as, for example, in Korea republic). The "below" variant is the creation of free economical zones in order of market self-organization (Dominican Republic, Poland).

More dynamic development pertains to the second variant, i.a. - in case of mixed public and private funding. The suppositions about formation of free economical zone are passed to specially authorized governmental federal or regional body that joins work on formation of conditions for its creation after adoption of decision of zone's formation.

We should also take into account the fact that practically all the SEZ are created as a result of mutual actions of central (federal) and regional authorities. Thereby, as a rule, the regulatory body consists of representatives of different levels of power, while the body itself is being under control of central and regional authorities.

The negative moment is the permanent uncertainty in prospects of Federal agency on special economical zones' management, the rumours of transformation and abolition of which occur quite regularly. The situation is being negatively perceived by foreign investors, who need reliable and long-term partner on behalf of government.

Besides, there are also technical difficulties that prevent investors from coming to Russian SEZ. For example, the process of getting status of resident of SEZ usually take several months, as it is necessary to conduct preliminary negotiations, work out the project in accordance with official requirements, get agreement of specialized institutions and corresponding regional authorities.

Thereby, the form of business-plan for official SEZ residents is approved by the Order of the Ministry of economical development of Russia of March 23, $2006 \# 75$, that is why there can be no free interpretations that are being acceptable for usual projects. The regulatory acts also fix the necessity of getting positive seclusion of bank for business-plan and coordinating the project with ROSIZO and the Ministry of economical development of the Russian Federation. In business-plans for potential resident of special economical zones the significant attention should be paid to assessment of social and economical effects due to realization of project (new working places, incomes to budget, multiplier effects, etc.). Such requirements are being not only superfluous for small- and mid-sized business entities, but also far not always clear for foreign companies.

There are also informal restrictions for entry of foreign investors to Russian SEZ. For example, the Chinese vehicle manufacturers Great Wall Motors had not taken authorization for creation of enterprise in industrial and production zone of Alabuga (Tatarstan), despite the compliance of business-plan with all the formal requirements and support of republic authority.

\section{Conclusion}

National economy has significant experience in formation of special economical zones. Starting with successfully implemented experience of China the Russian Federation was able to create original and independent project of SEZ. By 
the way of issuing and editing of new and existing regulatory acts there is improvement of mechanism of special economical zones' activity.

Under the modern conditions the legal framework of the Russian Federation is developed in direction of optimization of special economical zones' functioning, the matters of their functioning are worked out in detail.

The conducted analysis of SEZ development at mega-economical level, as well as at level of national economy allows making conclusion about existence of three main stages of development of economical idea about special economical zones that are characterized by extension of forms and limits of partnerships and international cooperation.

We should also specify the main tasks of creation and subsequent functioning of SEZ: 1) to promote diversification of national economy due to the development of knowledge-intensive branches of national economy; 2) to provide systematic re-setting of priorities from the branches of extracting industry to the branches of processing industry; 3 ) to perform integration of science into production that will activate innovative activity; 4) to attract leading technologies in respect of national technologies; 5) to activate economy, as the result of attraction of foreign capital; 6) to promote income of financial assets that increase the currency reserves; 7 ) to perform assistance in saturation of internal consumer market; 8) to increase the employment level of population and qualification of labour resources; 9) to create modern market infrastructure; 10) to improve development of depressed area; 11) the possibility of obtaining world's experience in the area of economy management and international entrepreneurship.

Analyzing mega-economical experience it is important to underline the fact that the model of SEZ has close interrelation with economical potential of country-organizer. One should agree with the opinion of some authors (Smorodinskaya N., Kapustin A., 1994) that the activity of zones is based on legal backgrounds on a scale of national economy and promotes dynamic development of national economy by means of attraction of new technologies, production capital and the best experience in management; testing of newest methods for economical activity based on combination of various property forms; implementation of national and foreign scientific and technical lay-outs to material production; saturation of national market with competitive production; increase of number of working places and reduction of unemployment level.

However, the presented results of economical zones' research can not be considered exhaustive, as far as in modern economical reality with dynamics and impermanence peculiar to it the need for development of internal markets of country and the necessity of searching for optimal and prospect conditions for functioning of special economical zones are grown.

\section{References}

Amitendu, P. (2008). Special economic xones in India. Myths and realities. 350 p.

Babaev, H. S. (2014). Regarding interrelation investment attractiveness free economic areas and fiscal policy. Tadjik State University of Law, Business and Politics Herald, 3, pp. 116-122.

Berezenkov, V. V., Gayduk V. I., Mihaylushkin P. V. (2010). Commercial activities. Krasnodar, 256 p.

Blinnikov, E. B., \& Leonidova, A. I. (2010). Free economic areas: essence, opportunities. Aktualnye problemy aviatcii i kosmonavtiki, Vol.2, 6, pp. 138-139.

Bräutigam, D., \& Xiaoyang, T. (March, 2011). The African Shenzhen: China's special economic zones. Africa Journal of Modern African , Vol. 49, Issue 01, pp. 27-54.

Geosite.ru (2004). Retrieved from: http:// geosite. com. ru / index, php? pa=list_pages_categories\&cid=6

Granberg, A. G. (2000). Regional economy basics. Moscow: Higher School of Economics. P. 500 p.

Korobova, O. V. (2010). Increase in investment activity of regions by means of creating free economic areas. Nauka na rubezhe tysyacheletiy, 9, pp. 8-9.

Korolev, Yu. A. (2010). Improvement of the institutional forms of region innovative development management based on special economic zones. (Ph.D. thesis in Economics). Kazan State Technologic University. Kazan. 25 p.

Krasnolutskaya, N.T. (2007). A special economical zone. Moscow: Blagovest,137 p.

Litovka O. P., \& Mezhevich N. M. (2002). Globalism and regionalism - tendencies of the world development and a factor of social and economic development of Russia. St. Petersburg: Kult-inform-press.

Mihaylushkin, P. V., Barannikov, A. A. (2013). Creation of special economic zones - upcoming trend of state priming of Russian economy. Kuban State Agrarian University Scientific Journal, 90(06), pp. 1-22.

Mironov, E. I. (April 13, 2010). Special economic zones as an effective instrument of innovation economy development: the principle of preferential cooperation. Aktualnye voprosy ekonomicheskih nauk: Proceedings of the 21th Research and Practice Conference. Novosibirsk, pp. 144-149.

Moberg, L. (2015). The political economy of special economic zones. Journal of Institutional Economics, 11, pp. 167-190.

Orlov, A. K., \& Buadze E. R. (2012). Innovation of value as an instrument of special economic zones competitive recovery. Privolzhsky nauchny zhurnal, 3, pp. 209-213.

Popova, M. V., \& Rubtsov, N. M. (2014). Analysis and evaluation of historical experience of Russia in the process of public management 
of creation and functioning of special economic zones. Teoriya i praktika obshhestvennogo razvitiya, 7, pp. 98-100.

Rybakov, S.A. (2006). Special economical zones in Russia. Tax incentives and advantages. Moscow: Grant, 165 p.

Shekhovtsov, A. (December, 2003). Free economic area: theory and practice of functioning across the world. "RTSETS" Herald, 132.

Shvetsova K.A. (2012). Enhancement of innovative activities stimulation in special economic zones (Synopsis of Ph.D. thesis in Economics). Russian Research and Development Center of Information by Standardization, Metrology, and Conformance evaluation. Moscow.

Sidorenko, V. V., \& Agasarov D. Ya. (2006). Development and regulation of agricultural business in Russia. Mezhdunarodny selskokhozyaistvenny zhurnal, 6.

Smorodinskaya, N., \& Kapustin, A. (1994). Free economic areas: global experience and Russian peocpects. Voprosy Ekonomiki, 12.

Special economic zones. Retrieved from: http://www.russez.ru/press/news/

The decree of Government of the Russian Federation of 04.26.2012 \#398 "Of approving criteria for creation of special economical zone" (May 8, 2012). Rossiyskaya gazeta.

The Decree of Government of the Russian Federation of December 21, 2013 \#2492-p "Of adopting the government program of the RF "Economic development and innovation-driven economy" (December 26, 2013). Rossiyskaya gazeta.

The decree of Government of the Russian Federation of June 21, 2013 \# 524 "Of procedure for granting in 2013 subsidies from the federal budget to management companies of special economic zone, as well as residents of tourist and recreational special economic zones that was combined to cluster by the decision of the Government (July 1, 2013). Rossiyskaya gazeta.

The Decree of the CPSU Central Committee and Ministry of the USSR of December 2, 1988 \#1405 "Of considering some decrees the CPSU Central Committee and the Council of Ministers of the USSR regarding labour and salary repealed" Retrieved from: http://www.referent.ru/1/35636 (access date 03.15.2014).

The Decree of the Russian Federation of June 10, 2013 \#491 "Of adoption of regulations of efficiency estimation of special economic zones functioning" (June 24, 2013). Rossiyskaya gazeta.

The Federal law of 01.22.1996 \#13-FL "Of special economical zone in Kaliningrad region". Retrieved from: http://www.consultant.ru/ document/cons_doc_LAW_57728/ (access date 03. 23.2014).

The Federal law of 05.31.199 \#104-FL "Of special economical zone in Magadan region". Retrieved from: http://www.consultant.ru/ document/cons_doc_LAW_148510/ (access date 03.23.2014).

The Federal law of 07.22.2005 \#116-FL "Of special economical zones in the Russian Federation" (July 27, 2005). Rossiyskaya gazeta.

The Federal law of July 23, 2013 \#231-FL "Of introducing changes to articles 4 and 10 of Federal law "Of special economical zones in the Russian Federation" (26 July, 2013). Rossiyskaya gazeta.

The Federal law of от 01.010.2006 \#16-FL "Of special economical zone in the Kaliningrad region and introduction of changes in some legal acts of the Russian Federation" (January 19, 2006). Rossiyskaya gazeta.

The Order of President of Russia of 02.25.1993 \# 280 "Of urgent measures on state support of establishing and social and economic development of the Ingushi Republic". Retrieved from: http://poisk-zakona.ru/249512.html (access date 03.16.2014).

The Order of President of Russia of December 10, 1992, "Of Sheremetievo free trade zone creation. Retrieved from: http://base.garant.ru/10104210/ (access date 03.15.2014).

The special economic zones of China and their impact on its economic development (1997). Jung-Dong Park. Westport, CT and London: Praeger. $219 \mathrm{p}$.

Ulyukaev, A.V. Russian Government session concerning "Forecast of social and economic development of the Russian Federation for 2014 u planning period of 2015 and 2016". Retrieved from: http://www.economy.gov.ru/wps/wcm/connect/economylib4/mer/ press/news/doc20131909_22.

Vasilenkova, N. V. (2014). Public-private partnership as a form of economic relations. Ekonomika. Innovatcii. Upravlenie kachestvom, 4(9). The section of "Economy of an enterprise of production and servicing". Voronezh, pp. 147-148. 